\title{
Metabolism and Excretion of Caffeine during Germination of Coffea arabica $\mathbf{L}$.
}

\author{
Thomas W. Baumann and Helene Gabriel
}

Institute of Plant Biology, University of Zurich, CH-8008 Zurich, Switzerland

\begin{abstract}
To investigate the physiological role of the purine alkaloids during germination, seeds of Coffea arabica were allowed to germinate under aseptic conditions on agar at $26^{\circ} \mathrm{C}$, either in the dark or in the light. After imbibition for 7 days less than $1 \%$ of the seed caffeine is found in the agar, indicating a strong diffusion barrier at the surface of the coffee bean. After 56 days, when the radicle has grown deep into the agar support, a considerable amount $(22 \%)$ of caffeine is excreted. The total caffeine content increases during germination for 56 days by $83 \%$ in the dark and by $51 \%$ in the light, whereas the soluble protein falls drastically. We propose that caffeine is not a nitrogen reserve for germination and acts against competitors (release into the soil) and against predators (concentration increase in the tissue).

Key words: Caffeine - Coffea arabica - Excretion - Germination - Nitrogen metabolism - Purine alkaloid - Theobromine.
\end{abstract}

There is a large body of information on the actual aspect of purine alkaloid physiology, published fifty or more years ago, which is difficult of access and in certain instances requires a re-examination with subtle methods allowing an improved insight into the physiological role of these alkaloids. At the beginning of this century U. Suzuki expressed clearly that in the tea plant "the processes of metabolism show more connection with the production of coffein than those of assimilation and synthesis do" (cited by Weevers 1930, p. 123). Later, Weevers (1907, 1930) carried out a detailed study on this topic in all caffeine-containing plant species consumed by man, i.e. tea (Camellia sinensis (L.) O. Kuntze), coffee (different species of Coffea), mate (Ilex paraguariensis St. Hil.), guarana (Paullinia cupana H.B.K.), cocoa (Theobroma cacao L.) and cola (Cola acuminata Schott et Endl.). He analyzed detached leaves and, where possible, seedlings, and always observed an increase in protein accompanied by a decrease in purine alkaloids or vice versa depending on the experimental conditions selected. As regards these events during seedling development of Coffea arabica, Weevers reported results from experiments in the dark only.

We decided therefore to examine the changes in different nitrogen fractions during germination of Coffea arabica $\mathrm{L}$. under controlled environmental conditions and to make a comparison on the physiology of caffeine between the coffee plant and other caffeine-containing plant species.

\section{Materials and Methods}

Plant material-Trees of Coffea arabica L. var. caturra were cultivated in the greenhouse (25$28^{\circ} \mathrm{C}$ ). Fruits of one harvest date were processed and stored (Valio 1976, Couturon 1980, Van der Vossen 1980) as follows: freshly plucked fruits were manually depulped, washed with water 
and treated at room temperature for 36 to $48 \mathrm{~h}$ with $0.01 \%$ pectinase (Fluka, Buchs, Switzerland; 100 seeds per $500 \mathrm{ml}$ enzyme solution). After several rinses with water, seeds still surrounded by the endocarp were dried at room temperature to a moisture content of about $40 \%$, irradiated for $15 \mathrm{~min}$ by a $40 \mathrm{~W}$ UV lamp, sealed in air-tight polyethylene bags and stored at $17.5 \pm 1.5^{\circ} \mathrm{C}$. In this way germination remained at $97 \%(n=240)$ during the entire period of investigation ( 1.5 years).

Culture conditions-The seeds were freed from the endocarp, then chemosterilized in calcium hypochlorite (saturated solution, $5 \mathrm{~min}$ ) and, after several rinses in sterile distilled water, they were aseptically transferred either onto water soaked cotton wool in a Petri dish (germination test) or onto $100 \mathrm{ml}$ of $0.6 \%$ agar (Phytagar, Gibco Lab., Grand Islands, U.S.A.) in $400 \mathrm{ml}$ screw-capped jam jars (Fig. 1 ; main experiments).

For the germination test a temperature gradient from 19 to $40^{\circ} \mathrm{C}$ with increments of about $1^{\circ} \mathrm{C}$ (Fig. 2) per chamber was installed. Each chamber contained two Petri dishes each with 5 seeds.

In the main experiments dealing with nitrogen metabolism during germination, the conditions were $26 \pm 1^{\circ} \mathrm{C}$, dark or light; after imbibition and after 4 and 8 weeks, fresh and dry weights, and the amounts of total nitrogen, soluble protein, caffeine and theobromine were determined. For each point of analysis 5 jars each with 5 seeds (Fig. 1) were processed. After fresh weight determination the plant material of two jars was pooled and pulverized in a mortar in liquid nitrogen. Aliquots were taken for dry weight and protein measurements. The plant material grown in the remaining 3 jars was dried at $80^{\circ} \mathrm{C}$, and finely ground and served for determinations of total nitrogen and of the purine alkaloids. The agar supports were dried $\left(80^{\circ} \mathrm{C}\right)$ and analyzed separately.

Analysis of total nitrogen and soluble protein-Total nitrogen was determined by the Kjeldahl method in aliquots of $200-300 \mathrm{mg}$ plant material or in the agar supports. Soluble protein was measured according to Schaffner and Weissmann (1973). For each determination 3 portions of $200 \mathrm{mg}$ plant material were extracted at room temperature for $1 \mathrm{~h}$ with $2 \mathrm{ml}$ of a $20 \mathrm{~mm}$ cysteine-HCl solution. After centrifugation the supernatant was filtered through cellulose filter paper. Out of the filtrate samples of 50, 100 and $200 \mu \mathrm{l}$ were taken for the protein test.

Determination of purine alkaloids-Caffeine and theobromine were quantified by the isotope

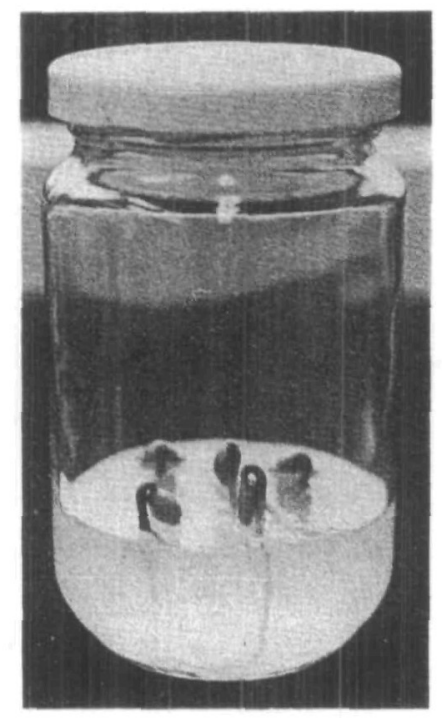

Fig. 1 Cultivation system used in the main experiments. As an example, 4-week-old seedlings of Coffea arabica grown under aseptic conditions $(0.6 \%$ agar, $26^{\circ} \mathrm{C}$, light) are shown. 
dilution method. To each sample $3,333 \mathrm{~Bq}{ }^{14} \mathrm{C}$-caffeine and ${ }^{14} \mathrm{C}$-theobromine (both in $35 \mu \mathrm{l}$ $\mathrm{H}_{2} \mathrm{O}$ and with a specific activity of $48 \mathrm{mCi} \cdot \mathrm{mmol}^{-1}$ ) were added, having been prepared according to Heftmann (1971) and to Frischknecht and Baumann (1979), respectively.

Extraction of 50 to $100 \mathrm{mg}$ plant material was carried out with 2 to $4 \mathrm{ml} 25 \mathrm{~mm}$ sulphuric acid at $90^{\circ} \mathrm{C}$ for $20 \mathrm{~min}$. After cooling, an aliquot of the extract, usually $0.5 \mathrm{ml}$, was transferred onto a diatomaceous earth column (Extrelut, Merck, Darmstadt, FRG; $0.6 \mathrm{~g} \cdot \mathrm{ml}^{-1}$ extract). Caffeine and theobromine were eluted with chloroform (12 times the extract volume). Agar supports were extracted separately, each with $10 \mathrm{ml}$ of $25 \mathrm{~mm}$ sulphuric acid. The entire extracts were then purified on properly sized diatomaceous earth columns.

After evaporation of the solvent the residues were dissolved in $25 \%$ methanol, filtrated if turbid through a $0.45 \mu \mathrm{m}$ filter (HATF, Milipore, Bedford, U.S.A.). Then the samples were chromatographed on a data processing high performance liquid chromatograph (Waters Associates, Milford, U.S.A.) equipped with a $4 \times 300 \mathrm{~mm}$ column (10 $\mu \mathrm{m}$ LiChrosorb RP-18, Merck) and with a UV detector monitoring the eluant at $271 \mathrm{~nm}$. Theobromine and caffeine were eluted with $25 \%$ methanol. The capacity factor $k^{\prime}$ was 2.2 and 5.2 , respectively. Because of the quite different order of magnitude of caffeine and theobromine concentration, two separate chromatographic runs with different sample volume size were made. The corresponding peaks were collected and the radioactivity, usually 15 to $20 \mathrm{~Bq}$, was measured by liquid scintillation counting. Since the amount of purine alkaloids isolated from plant tissues is much higher than the amount of tracer added, absolute values are obtained by multiplying the amount of isolated substance with the ratio of initial radioactivity to isolated radioactivity.

\section{Results}

Temperature optimum of germination-To characterize the degree of germination the root weight was expressed in percentages of the total seedling weight (Fig. 2). The temperature optimum lies roughly between 25 and $27^{\circ} \mathrm{C}$. There is almost no germination at $35^{\circ} \mathrm{C}$.

Nitrogen metabolism during imbibition and germination-After the 7-day-period of imbibition dry weight (Fig. 3a) and caffeine content (Fig. 3b) are not changed significantly. Endogeneous theobromine (Fig. 3c) decreases from 29 to $14 \mu \mathrm{g}$. Compared with the initial seed alkaloid content, the amount found in the surrounding medium is high for theobromine $(68 \mu \mathrm{g}, 235 \%)$ and extremely low for caffeine $(11 \mu \mathrm{g}, 0.8 \%$ ). Soluble protein (Fig. 3d) has increased by $53 \%$.

During germination in the light as well as in the dark (Fig. 3; 28 and 56 days) a considerable increase in fresh weight is accompanied by a slight decrease in dry weight. The theobromine content of both seedling and agar is low during the entire experiment. After 28 days the caffeine content of the seedling is distinctly lower (light $1,075 \mu \mathrm{g}$, dark $1,120 \mu \mathrm{g}$ ) than that of the ungerminated seed $(1,350 \mu \mathrm{g})$, probably because of excretion into the agar. Later, after 56 days the total amount (agar caffeine included) per seedling is greatly increased compared to the seed, namely by $51 \%$ in the light and by $83 \%$ in the dark. In contrast, the level of soluble protein falls from $2,290 \mu \mathrm{g}$ (imbibed seed) to $30 \mu \mathrm{g}$ (light) or $60 \mu \mathrm{g}$ (dark) during the same period. Total nitrogen (data not shown) is fairly constant $(2.49 \pm 0.11 \mathrm{mg}$; S.D.) during the entire time of observation. Four and $8 \%$ of it are present in the agar after 28 and 56 days, respectively. Two thirds of this nitrogen are to be attributed to purine alkaloids.

\section{Discussion}

During seed imbibition leakage of caffeine into the agar support is extremely small, indicating the existence of a strong diffusion barrier at the seed surface. This barrier does not seem to be 

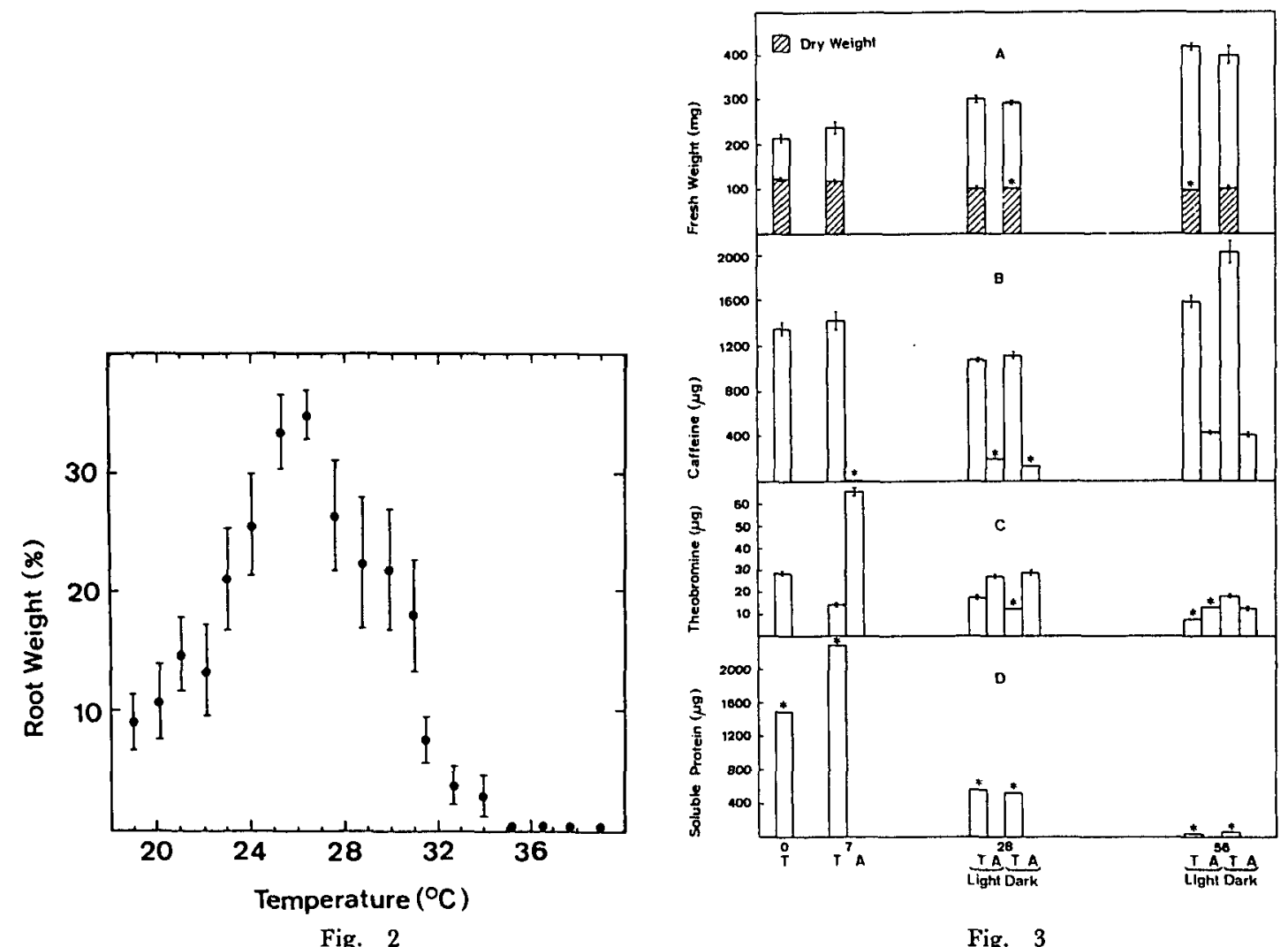

Fig. 2

Fig. 3

Fig. 2 Temperature optimum of germination. The root weight is expressed in percentages of the total seedling weight (fr wt; mean \pm S.D.; $n=10$ ).

Fig. 3 Fresh and dry weights (a), and content of caffeine (b), theobromine (c) and soluble protein (d) determined after 7 (imbibition), 28 and 56 days of germination in light or dark. Each value represents the mean of triplicate determinations \pm S.E. Ten seeds or seedlings were processed for weight and protein measurements and 15 for purine alkaloid analyses. $\mathrm{T}=$ tissue, $\mathrm{A}=\mathrm{agar}$ * S.E. value too small for graphical reproduction. To calculate the purine alkaloid nitrogen values, the amounts of caffeine and theobromine must be divided by 3.47 and 3.22 , respectively.

"testa-mediated", since the very thin and fragile "silverskin" already decays during preparation of the seeds as described in the section Materials and Methods. The nature of the seed diffusion barrier for caffeine may be attributed to chlorogenic acid which has been reported to be concentrated in the cuticular layers (Dentan 1977) and which forms a strong and hydrophobic complex with caffeine (Horman and Viani 1972, Kappeler and Baumann, unpublished data).

Later during germination, when the radicle grows into the agar support, a considerable amount of caffeine is excreted to yield an average concentration of $265 \mathrm{ppm}$ in the agar (Fig. 3). Caffeine concentrations of this range have been reported to be inhibitory on germination of the tropical weed, Amaranthus spinosus (Rizvi et al. 1981). Since there is undoubtedly a concentration gradient in the rhizosphere, caffeine concentration in the immediate neighbourhood of the roots is expected to be much higher.

The positive caffeine balance (Fig. 3) observed during our germination studies is not in accordance with the results of Friedman and Waller (1983), who showed a loss of $13 \%$ of the 
Table 1 Purine alkaloids during germination

\begin{tabular}{|c|c|c|c|}
\hline \multirow{2}{*}{ Species } & \multicolumn{2}{|c|}{ Alkaloid content (mg) } & \multirow{2}{*}{ Conditions } \\
\hline & Per seed & After germination & \\
\hline \multirow{2}{*}{$\begin{array}{l}\text { Camellia sinensis" } \\
\text { ("Thea assamica") }\end{array}$} & 0.5 & 3.18 & dark, $60 \mathrm{~d}$ \\
\hline & & 1.92 & light, $60 \mathrm{~d}$ \\
\hline \multirow{2}{*}{$\begin{array}{l}\text { Camellia sinensis" } \\
\text { ("Thea sinensis") }\end{array}$} & - & 2.2 & dark, $70 \mathrm{~d}$ \\
\hline & & 1.5 & light, $70 \mathrm{~d}$ \\
\hline \multirow[t]{2}{*}{ Coffea arabica ${ }^{c}$} & 1.35 & 2.04 & dark, $56 \mathrm{~d}$ \\
\hline & & 1.63 & light, $56 \mathrm{~d}$ \\
\hline \multirow[t]{2}{*}{ Coffea liberica ${ }^{a, d}$} & 4.62 & 4.88 & dark, $60 \mathrm{~d}$ \\
\hline & & 4.37 & light, $60 \mathrm{~d}$ \\
\hline Cola acuminata $^{a}$ & 207.0 & 75.0 & light \\
\hline \multirow[t]{4}{*}{ Theobroma cacao } & $7.40^{T}$ & $2.23 \mathrm{~T}$ & light, $21 \mathrm{~d}$ \\
\hline & 6.43 & 10.68 & light, $21 \mathrm{~d}$ \\
\hline & & $4.25 \tau$ & dark, $21 \mathrm{~d}$ \\
\hline & & 10.12 & dark, $21 \mathrm{~d}$ \\
\hline
\end{tabular}

$\bar{a}$ Weevers $(1907,1930) ;{ }^{b}$ Konishi et al. (1972); ${ }^{c}$ these studies; ${ }^{d}$ this species has been shown recently (Petermann and Baumann 1983) to convert caffeine into methyluric acids, a class of substances not envisaged by Weevers. Thus these values must be interpreted with caution.

$\tau$, theobromine.

seed caffeine, already within 4 weeks of germination. The discrepancy is due to the non-sterile germination system used by these authors, in which uncontrolled microbial breakdown of caffeine occurs (unpublished data).

During germination of Coffea arabica there is an increase in the total amount of caffeine nitrogen per seedling corresponding almost exactly to the decrease in nitrogen of soluble protein (calculated from Fig. 3; 56 days). More caffeine is produced in the dark than in the light. We suggest therefore that the caffeine of the coffee seed acts primarily not as a nitrogen storage pool, but rather has an ecological significance in as much as during the critical phase of germination the seedling is protected against competitors by release of caffeine into the soil, and against predators by its accumulation in the vegetative plant parts. The extremely small content in soluble protein may contribute additionally to a low dietary value.

It would be of great importance to know whether a secondary compound such as caffeine may have different ecological significance in different plant species. Data from literature together with the results of this study were therefore summarized in Table 1. Although the experimental conditions were not exactly the same in all species examined, it is evident that, with the exception of Cola, the absolute amount of caffeine increases during germination. Since in this period of plant development the dry weight is constant or even falls, the tissue concentration of caffeine reaches a considerable value, which supports the defense hypothesis for the tea, coffee and cocoa plant. In cola-young seedlings spontaneously germinated under cola trees were analyzed - the seed caffeine may have the function of a nitrogen reserve which is utilized during germination. But additional investigations need to be carried out in order to prove such a role.

We were financially assisted in this work by the Swiss National Science Foundation. We thank Dr. Vera Klein-Williams for correcting the English text. 


\section{References}

Couturon, E. (1980) Le maintien de la viabilité des graines de caféiers par le contrôle de leur tencur en eau et de la température de stockage. Café Cacao Thé 24: 27-31.

Dentan, E. (1977) Structure fine du grain de café vert. 8. Colloque International sur la Chimie des Cafés verts, Abidjan, (ASIC, Paris) pp. 59-64.

Friedman, J. and G. R. Waller (1983) Caffeine hazards and their prevention in germinating seeds of coffee. $J$. Chem. Ecol. 9: 1099-1106.

Frischknecht, P. M. and T. W. Baumann (1979) Synthesis of $[2-14 \mathrm{C}]$ theobromine. J. Labelled Compd. 16: 669-672. Heftmann, E. (1971) Synthesis of caffeine-2-14C. J. Labelled Compd. 7: 463-465.

Horman, I. and R. Viani (1972) The nature and conformation of the caffeine-chlorogenate complex of coffee. J. Food Sci. 37: 925-927.

Konishi, S., M. Ozasa and E. Takahashi (1972) Metabolic conversion of $N$-methyl carbon of glutamylmethylamide to caffeine in tea plants. Plant $\mathcal{E}^{2}$ Cell Physiol. 13: 365-375.

Petermann, J. P. and T. W. Baumann (1983) Metabolic relations between methylxanthines and methyluric acids in Coffea L. Plant Physiol. 73: 961-964.

Rizvi, S. J. H., D. Mukerji and S. N. Mathur (1981) Selective phytotoxicity of 1,3,7-trimetylxanthine between Phaseolus mungo and some weeds. Agric. Biol. Chem. 45: 1255-1256.

Schaffner, W. and C. Weissmann (1973) A rapid, sensitive, and specific method for the determination of protein in dilute solution. Anal. Biochem. 56: 502-514.

Valio, I. F. M. (1976) Germination of coffee seeds (Coffea arabica L. cv. Mundo Novo). J. Exp. Bot. 27: 983-991.

Van der Vossen, H. A. M. (1980) Methods of preserving the viability of coffee seeds in storage. Kenya Coffee 45: 31-35.

Weevers, T. (1907) Die physiologische Bedeutung des Koffeins und des Theobromins. Ann. Jard. Bot. Buitenzorg 2e Serie, 6: 1-78.

Weevers, T. (1930) Die Funktion der Xanthinderivate im Pflanzenstoffwechsel. Arch. Neerl. Sci. III B 5: 111-195.

(Received June 5, 1984; Accepted August 29, 1984) 